\title{
Microbial stimulation of the aggregation process between submicron-sized particles and suspended particles in coastal waters
}

\author{
Hideki Fukuda*, Isao Koike \\ Ocean Research Institute, University of Tokyo, 1-15-1, Minamidai, Nakano, Tokyo 164-8639, Japan
}

\begin{abstract}
Transfer rates of submicron-sized particles (SMP) to micro-suspended particles (5 to $20 \mu \mathrm{m}$ in diameter) in coastal waters around Japan were measured using fluorescent beads $(0.5 \mu \mathrm{m}$ in diameter) and flow cytometry, with and without metabolic inhibitors (thiuram or $\mathrm{NaN}_{3}$ ). This flow cytometric technique has the advantage that it allows the number of beads stuck to suspended particles to be counted without any pre-treatment, such as filtration, that can introduce artifacts. The transfer rates to particles in the 5-20 $\mu \mathrm{m}$ fraction without inhibitors were on average 4.3 to 5.8 times higher than with added $\mathrm{NaN}_{3}$. On the other hand, ingestion rates of fluorescent beads by protozoa in the 5-20 $\mu \mathrm{m}$ fraction were less than $10 \%$ of the transfer rates to particles in the $5-20 \mu \mathrm{m}$ fraction. These results indicate that biological activities were more efficient than physical mechanisms for the transfer process of SMP into the 5-20 $\mu \mathrm{m}$ fraction separately from the grazing process. Also, the inhibitory effect of thiuram on the transfer rates suggests an involvement of eukaryotic cells in this stimulation. The intensity of this stimulation was positively correlated with the density of attached nanoflagellates per particle (Da) $(\mathrm{R}=0.630, \mathrm{n}=22)$, bacterial abundance $(\mathrm{R}=0.489, \mathrm{n}=22)$, concentration of chlorophyll a $(\mathrm{R}=0.518, \mathrm{n}=18)$ and water temperature $(\mathrm{R}=0.569, \mathrm{n}=22)$. These results indicate that biological processes are key mechanisms for the coagulation process of submicro- and micro-scale particles in coastal environments.
\end{abstract}

KEY WORDS: Particle aggregation $\cdot$ Colloidal particles $\cdot$ Sinking flux $\cdot$ Microbial food web $\cdot$ Collision efficiency $\cdot$ Sickness $\cdot$ Extracellular release

Resale or republication not permitted without written consent of the publisher

\section{INTRODUCTION}

Submicron particles (SMP, 0.4 to $1 \mu \mathrm{m}$ ) belong to the larger group within the size range of marine colloids ( 0.001 to $1 \mu \mathrm{m}$ ) and are one of the most abundant particles classes in marine environments, consisting mainly of organic materials produced by plankton (Koike et al. 1990). Through the adsorption process of inorganic and organic compounds, SMP play a significant role in material transfer in planktonic food webs (Nagata \& Koike 1995, Quigley et al. 2002, Kerner et al. 2003).

Much attention has been paid to physical aggregation processes as the major factor controlling the fate of various particles in marine environments. Aggregation processes were examined by comparing field data or laboratory experiments with aggregation models describing the physico-chemical behavior of particles
(McCave 1984, Jackson \& Burd 1998, Mari \& Burd 1998). Classical coagulation theory focuses on 3 particle collision mechanisms: Brownian motion, laminar and turbulent shear, and differential sedimentation (reviewed in Jackson \& Burd 1998). However, biological activities are also, occasionally indispensable, factors in the aggregation process (Biddanda 1985). Planktonic organisms produce particulate organic matter, increase particle collision frequency (Johnson \& Kepkay 1992, Fukuda \& Koike 2000) and increase particle stickiness (Kiørboe \& Hansen 1993, Passow 2000).

In previous studies, relative importance of biological processes and physico-chemical processes in particle aggregation was examined by observing the amount of aggregates in cultures with or without biological activities (reviewed in Biddanda 1985). Therefore, it was dif- 


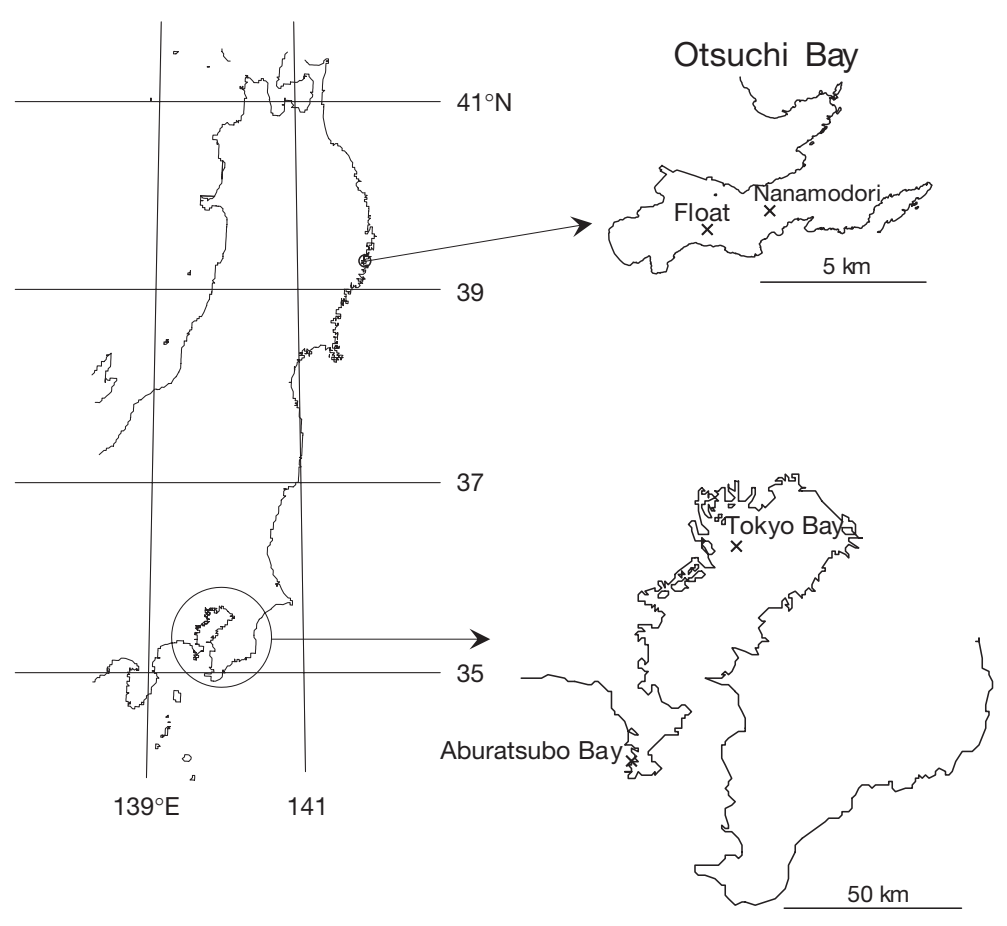

Fig. 1. Study sites $(x)$ in Tokyo Bay, Otsuchi Bay and Aburatsubo Bay

$\mathrm{HCl}$ and Milli-Q water. Tokyo Bay samples $\left(35^{\circ} 34^{\prime} \mathrm{N}, 139^{\circ} 49^{\prime} \mathrm{E}\right)$ were collected by a 241 Van Dorn sampler. Aburatsubo Bay samples $\left(35^{\circ} 54^{\prime} \mathrm{N}, 139^{\circ} 20^{\prime} \mathrm{E}\right)$ were collected from a pier, using a metal jug, which was washed with detergent and then rinsed with Milli-Q water.

To examine the role of the microbial community associated with settling particles on the SMP collision process, settling organic aggregates and associated microorganisms were collected by using a sediment trap at the station (Float or Nanamodori) in Otsuchi Bay. Two sediment traps, which had square meshed mouths (23 cm in diameter), were moored $15 \mathrm{~m}$ from the bottom of Float or Nanamodori stations for ca. $48 \mathrm{~h}$. The trap was washed with detergent and Milli-Q water, but the acrylic cups were washed with $\mathrm{HCl}$ and Milli-Q water. To fill the trap before the mooring, we used seawater filtered through a polycarbonate filter (pore size: $5 \mu \mathrm{m}$; Whatman) or a GF/C filter (Whatman). This procedure was to remove large particles, but to keep

ficult to quantify the relative contributions of biologicaland physico-chemical processes to aggregation. To understand the role of biological activities in marine particle dynamics, however, it is crucial to obtain the coagulation rate with and without biological processes using ambient seawater samples.

This study quantitatively examined the contribution of biological processes to the transfer process of SMP onto micro-suspended particles (5 to $20 \mu \mathrm{m}$ in diameter) in coastal waters by using fluorescent beads as model SMP (0.5 $\mu \mathrm{m}$ in diameter) and flow cytometric technique. Transfer rates of fluorescent beads to particles in the 5-20 $\mu \mathrm{m}$ fraction were compared with biological and other parameters obtained in coastal waters, to examine the factors controlling biological stimulation of SMP aggregation transferred into particles in the 5-20 $\mu \mathrm{m}$ fraction.

\section{MATERIALS AND METHODS}

Study site and sample collection. The incubation experiments were conducted by using seawater samples collected from the coastal area of Japan. Fig. 1 summarizes the location of each station and the date of the survey. In Otsuchi Bay, the samples were collected by a 51 Van Dorn sampler at the center of the bay $\left(39^{\circ}\right.$ $\left.20^{\prime} \mathrm{N}, 141^{\circ} 56^{\prime} \mathrm{E}\right)$, or from the pier $\left(39^{\circ} 20^{\prime} \mathrm{N}, 141^{\circ} 57^{\prime}\right.$ E) with a plastic bucket. The bucket was washed with small particles such as bacteria as food for possible suspension feeding protozoa on settling particles during a ca. $48 \mathrm{~h}$ mooring time. Collected aggregates were resuspended and diluted with filtered seawater using a similar procedure for use in the experiments. During all of the sampling procedures, plastic gloves were worn to minimize the contamination by organic and inorganic compounds.

Transfer rate of fluorescent beads to 5-20 $\mathrm{\mu m}$ particles by natural microbial assemblages. Experiments were designed to observe the stimulation of fluorescent bead $(0.5 \mu \mathrm{m})$ attachment to particles in the $5-20 \mu \mathrm{m}$ fraction by microbial assemblages in coastal seawater. Since solid surfaces are negatively charged in solution in most cases, carboxylate-modified beads were chosen as tracer particles (Molecular Probes). The water samples or the re-suspended organic aggregates were filtered through a $94 \mu \mathrm{m}$ mesh net to remove net-zooplankton and then split into four $250 \mathrm{ml}$ polycarbonate bottles. Two controls were also prepared, one with the eukaryotic inhibitor, thiuram (final concentration $20 \mu \mathrm{M}$; Taylor \& Pace 1987) and the other with an inhibitor of the respiratory chain (sodium azide; final concentration $0.02 \%$, w/v). One subsample and 2 controls were amended with fluorescent beads (final concentration $1.5 \times 10^{6}$ particles $\mathrm{ml}^{-1}$ ) and incubated for 24 or $36 \mathrm{~h}$ at in situ temperature $\left( \pm 1.5^{\circ} \mathrm{C}\right)$ in the dark. One of the subsamples was used to determine the ingestion rate, biological parameters and the 
number of particles in the 5-20 $\mu \mathrm{m}$ fraction. The other subsample was incubated under the same conditions without the addition of fluorescent beads. For Tokyo Bay samples, however, the incubation was conducted at $20^{\circ} \mathrm{C}$, which was close to the in situ temperatures of 24,22 and $22^{\circ} \mathrm{C}$ at 0,10 and $16 \mathrm{~m}$, respectively.

The abundance of beads associated with particles in the $5-20 \mu \mathrm{m}$ fraction was monitored every 6 or $8 \mathrm{~h}$ during the incubation using a flow cytometer (BRYTE, Bio-Rad; Fukuda \& Koike 2000). The flow cytometers were equipped with a $100 \mu \mathrm{m}$ orifice and 2 filters: 470 to $490 \mathrm{~nm}$ and 515 to $565 \mathrm{~nm}$ for excitation and emission, respectively. Fluorescent beads sticking onto particles in the 5-20 $\mu \mathrm{m}$ fraction were distinguished from mono-dispersed beads in the solution by increases in the signals of forward angle light scattering, which was calibrated by comparison with the standard latex beads $(1.18,5.06,10.0$ and $17.6 \mu \mathrm{m}$ in diameter; Beckman-Coulter). The number of fluorescent beads on a particle in the 5-20 $\mu \mathrm{m}$ fraction was estimated from the intensity of yellow-green fluorescence assuming that fluorescence increases linearly with increasing number of beads included in the aggregate. Autofluorescence of suspended particles in the 5-20 $\mu \mathrm{m}$ fraction under the combination of excitation and emission filters was less than $25 \%$ of single fluorescent beads (data not shown). Quenching of fluorescence from the opposite side of the suspended particle, however, may occur, which would cause an underestimation of the number of transferred beads. The number of beads on particles in the $5-20 \mu \mathrm{m}$ fraction in $75 \mu \mathrm{l}$ of subsamples was counted 3 times for each sample.

During the middle of the incubation period, an experiment to determine ingestion rates of beads by protozoa was conducted. A subsample was amended with fluorescent beads (final concentration $1.5 \times 10^{6}$ particles $\mathrm{ml}^{-1}$ ) and incubated in the dark for $15 \mathrm{~min}$ at the same temperature as the 24 or $36 \mathrm{~h}$ incubation experiments. To observe the initial accumulation process into the protozoan food vacuole, ingestion rate was obtained from a 15 min incubation period, since the number of fluorescent beads in the food vacuole saturates at about $20 \mathrm{~min}$ (Sherr et al. 1987). After incubation, the sample was fixed with ice-cold glutaraldehyde and the number of beads in food vacuoles was counted to estimate the ingestion rates of flagellates and ciliates (Sherr et al. 1987). Organisms were stained by FITC and DAPI (Sherr \& Sherr 1983) to discriminate between beads attached to cell surfaces and those ingested. Counting was conducted 3 times for each sample and at least 400 or 500 attached eukaryotes were counted in all. The detection limit of ingestion rate is 1.0 or $0.80 \times 10^{-2}$ beads cell ${ }^{-1} \mathrm{~h}^{-1}$, respectively. During the middle of the incubation period, samples for the determination of biological and other parameters (abundance of bacteria, free-living nano- flagellates and attached nanoflagellates, chlorophyll a (chl a), total number of particles in the 5-20 $\mu \mathrm{m}$ fraction and density of attached nanoflagellates per 5-20 $\mu \mathrm{m}$ particle) were also collected from untreated incubations without the addition of fluorescent beads.

Subsamples for the determination of bacterial abundance and the number of particles in the 5-20 $\mu \mathrm{m}$ fraction were fixed with formaldehyde (final concentration $2 \%, v / v)$, whereas those for the determination of abundance of nanoflagellates were fixed with glutaraldehyde (final concentration $1 \%, \mathrm{v} / \mathrm{v}$ ). These fixed samples were stored at $4^{\circ} \mathrm{C}$ in the dark until analysis. Subsamples for determination of chl a were immediately filtered on $\mathrm{GF} / \mathrm{F}$ filters and then stored at $-20^{\circ} \mathrm{C}$ in the dark.

Determination of biological parameters and abundance of particles in the 5-20 $\mu \mathrm{m}$ fraction. Bacterial abundance was counted directly by epifluorescence microscopy after DAPI staining (Porter \& Feig 1980), whereas those of free-living and attached nanoflagellates were counted after staining with DAPI and FITC without discriminating pigmented or non-pigmented cells (Sherr \& Sherr 1983). Attached nanoflagellates were differentiated from nanoflagellates by checking the contact of nanoflagellates with particles under epifluorescent microscopy. After counting, the number of attached nanoflagellates was doubled to account for them on the invisible side of particles (modification of Caron 1987). Chl a concentrations were determined using fluorometry (Fluorometer 10-AU, Turner Designs; Holm-Hansen et al. 1965) after extraction with $\mathrm{N}, \mathrm{N}$-dimethylformamide (Suzuki \& Ishimaru 1990) at $-20^{\circ} \mathrm{C}$ for more than $2 \mathrm{~d}$. The number of particles in the 5-20 $\mu \mathrm{m}$ fraction was determined by using a coulter particle counter (Multisizer II, Beckman Coulter) equipped with a $50 \mu \mathrm{m}$ orifice. The density of attached nanoflagellates was calculated by dividing the abundance of attached nanoflagellates by the number of particles in the 5-20 $\mu \mathrm{m}$ fraction.

Statistical analysis. All of the statistical analyses were conducted using Sigma Stat (SPSS). The transfer rate of fluorescent beads was calculated from the time course, applying linear regression. The difference among transfer rates and ingestion rates were examined with a $t$-test. To examine the relationship between the transfer rate and other variables, Model II regression (Ricker 1973) was used. For regression analysis, log transformed variables were used to test whether the KolmogorovSmirnov distance was made smaller by the transformation. A backward stepwise multiple linear regression analysis was used to examine whether the variable was useful for explaining the variation of the dependent variable. At each step of the analysis, the independent variable was removed if its $F$-value was the minimum among independent variables and was lower than 2 . 


\section{RESULTS}

\section{Vertical profiles of transfer rates of fluorescent beads to particles in the 5-20 $\mathrm{\mu m}$ fraction at Tokyo Bay and Otsuchi Bay}

Fig. 2 shows vertical profiles of water temperature, salinity, total number of particles in the 5-20 $\mu \mathrm{m}$ fraction, microbial cell abundance, concentration of chlorophyll a ( $\mathrm{chl}$ a) and density of attached nanoflagellates at the Tokyo Bay station on 29 September

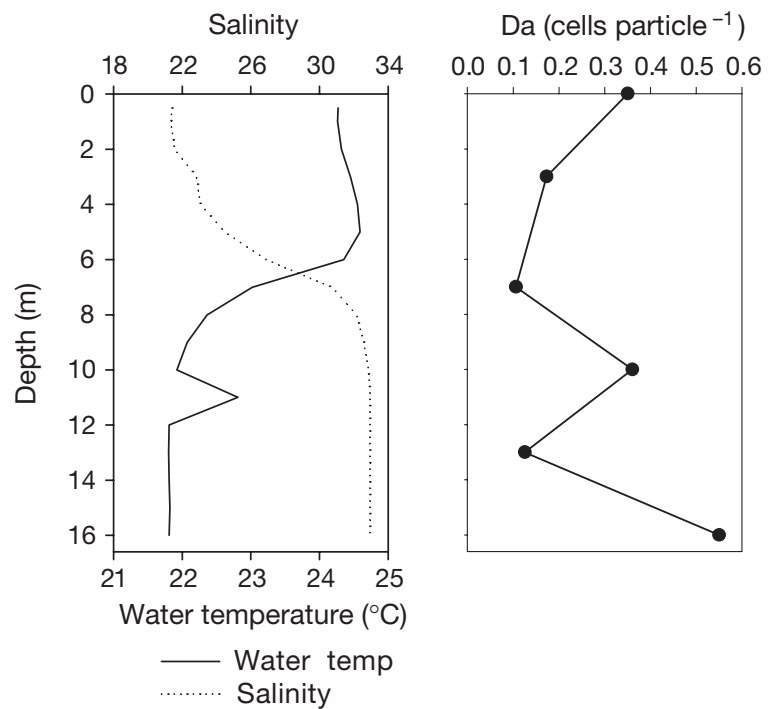

Particles in 5-20 m fraction Bacteria $\left(10^{6}\right.$ cells $\left.\mathrm{ml}^{-1}\right)$ (particles $\mathrm{m}^{-1}$ )

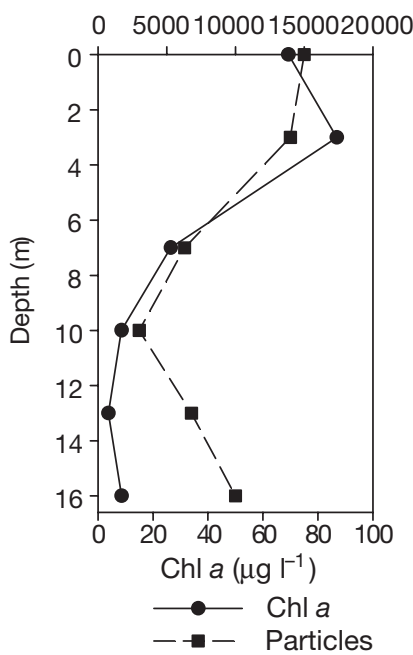
FF and $\mathrm{AF}\left(10^{3}\right.$ cells $\left.\mathrm{ml}^{-1}\right)$

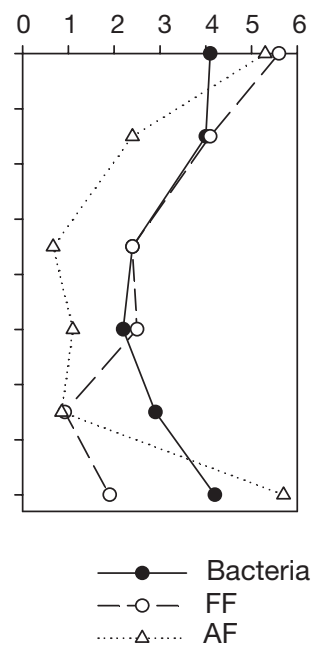

Fig. 2. Vertical profiles of water temperature, salinity, density of attached nanoflagellates (Da), total particle number in the 5-20 $\mu \mathrm{m}$ fraction, concentration of chlorophyll a (chl a), bacterial abundance (Bacteria) and abundance of free-living or attached nanoflagellates (FF or AF, respectively) at Tokyo Bay on 29 September 1999
1999. The surface mixed layer was about 4 to $5 \mathrm{~m}$ deep. The thermocline and halocline were located at a depth of ca. 5 to $7 \mathrm{~m}$. Chl $\mathrm{a}$ in the $0-3 \mathrm{~m}$ layer was very high (65 to $85 \mu \mathrm{g} \mathrm{l}^{-1}$ ) and decreased sharply below that depth. On the other hand, the number of particles in the 5-20 $\mathrm{mm}$ fraction had a minimum value at $10 \mathrm{~m}$, suggesting accumulation and/or resuspension of settled organic detritus near the bottom (16.6 m) (Fig. 2). Incubation experiments were conducted using the water samples collected from the surface, from $10 \mathrm{~m}$, where the number of particles in the 5-20 $\mu \mathrm{m}$ fraction was at a minimum, and from the bottom, where an increased number of particles in the 5-20 $\mu \mathrm{m}$ fraction was observed.

Fig. 3 shows the time course of the number of fluorescent beads on particles in the 5-20 $\mu \mathrm{m}$ fraction using the samples collected from 0,10 and $16 \mathrm{~m}$. The measured transfer rates in untreated cultures were 3.5 to 8.5 times higher than those in $\mathrm{NaN}_{3}$-treatment $\left(\mathrm{V}_{\mathrm{N}} / \mathrm{V}_{\mathrm{A}}\right)$ (Table 1$)$. The $\mathrm{V}_{\mathrm{N}} / \mathrm{V}_{\mathrm{A}}$ ratios showed some decrease with depth, although all of the ratios were significantly higher than 1 $(p<0.001)$. The differences between those treated with thiuram and $\mathrm{NaN}_{3}$ were not significant or smaller than those with no treatment. The number of fluorescent beads in the food vacuoles of microorganisms in the 5-20 $\mu \mathrm{m}$ size range did not increase significantly $(p>0.05)$ in all incubations (Table 1). From the abundance of attached nanoflagellates and the detection limit of ingestion rate $\left(1.0\right.$ or $0.80 \times 10^{-2}$ beads cell $\left.{ }^{-1} \mathrm{~h}^{-1}\right)$, the contributions of ingestion rate by the population of attached nanoflagellates to the transfer rate in the untreated incubations were less than $5 \%$.

Similar depth profiles of the transfer rates and environmental and biological parameters were also obtained using Otsuchi Bay samples collected on 24 May 2000 (Fig. 4, Table 1). Low salinity between depths of 1 to $2 \mathrm{~m}$ was probably caused by river inflow. Chl $\mathrm{a}$ in the bay ranged from 1 to $2 \mu \mathrm{g} \mathrm{l}^{-1}$ within the top $13 \mathrm{~m}$ and decreased sharply towards the bottom at a depth of $44 \mathrm{~m}$ (Fig. 4). The number of particles in the 5-20 $\mathrm{mm}$ fraction at Otsuchi Bay $\left(2.1\right.$ to $4.1 \times 10^{2}$ particles $\mathrm{ml}^{-1}$ ) was more than 1 order of magnitude lower compared to those samples from Tokyo Bay in the summer (3.0 to 15 $\times 10^{3}$ particles $\mathrm{ml}^{-1}$ ). The number of particles in the 5-20 $\mu \mathrm{m}$ fraction had a minimum at a depth of $13 \mathrm{~m}$ and then increased remarkably with depth towards the bottom. The transfer rates in untreated incubations were significantly higher than those in $\mathrm{NaN}_{3}$-treatment incubations except at a depth of $42 \mathrm{~m}(\mathrm{p}<0.001)$, and the $\mathrm{V}_{\mathrm{N}} / \mathrm{V}_{\mathrm{A}}$ ratio varied drastically from 1.4 at a depth of $42 \mathrm{~m}$ to 10 at the surface. Similarity in vertical trends between the $\mathrm{V}_{\mathrm{N}} / \mathrm{V}_{\mathrm{A}}$ ratio and other parameters was not observed (Fig. 4, Table 1). The contribution of ingestion by protozoa to the transfer rate was less than $10 \%$ in these incubations. 


\section{Changes in transfer rates of fluorescent beads \\ to particles in the $5-20 \mu \mathrm{m}$ fraction at Otsuchi Bay and Aburatsubo Bay}

Using surface waters of Otsuchi Bay, periodic changes in biological parameters and in the transfer rates of fluorescent beads to particles in the 5-20 $\mu \mathrm{m}$ fraction were examined from February to May 2000 (Fig. 5, Table 2). Water temperature decreased slightly from February to April and then increased rapidly in May (Fig. 5). The number of particles in the 5-20 $\mu \mathrm{m}$

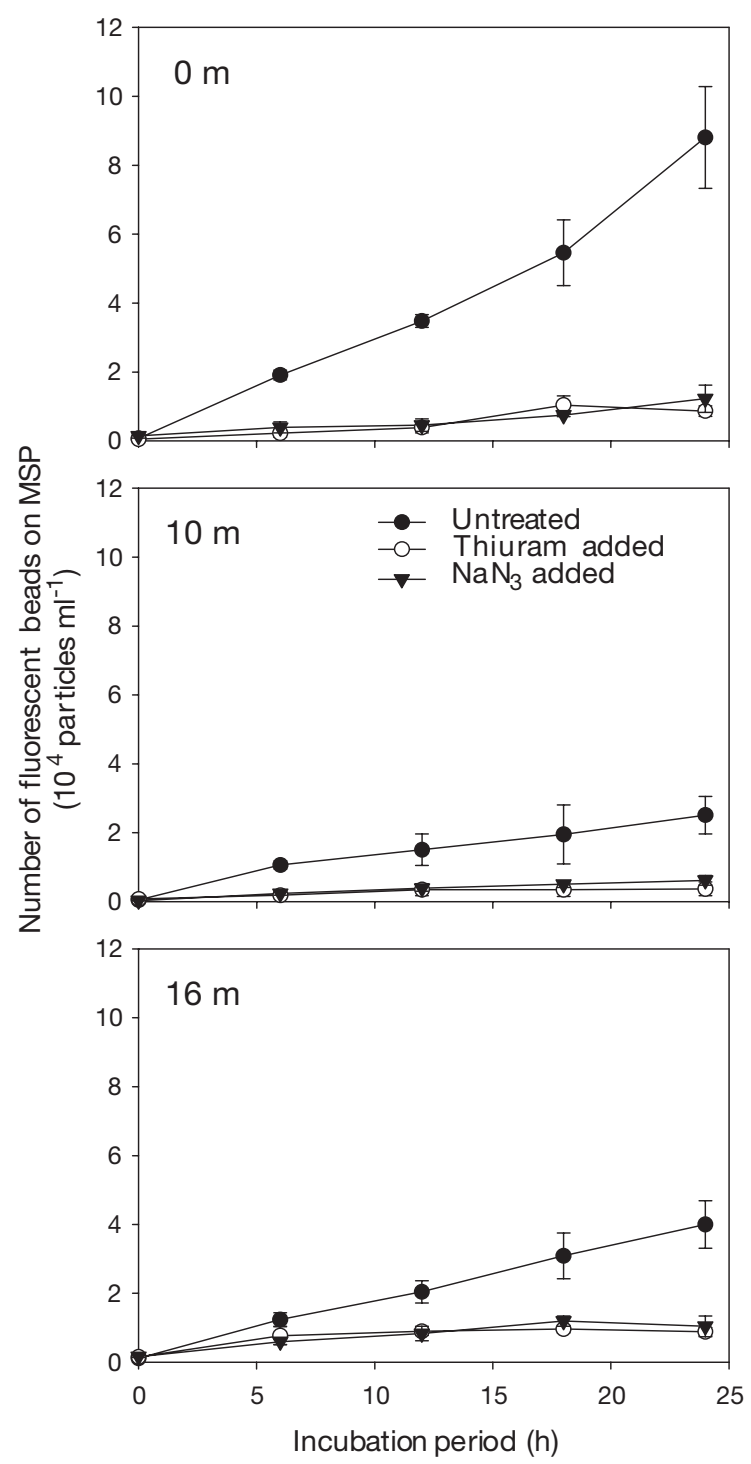

Fig. 3. Time course of the number of fluorescent beads on 5-20 $\mu \mathrm{m}$ particles in 3 different cultures: untreated, thiuram added, and $\mathrm{NaN}_{3}$ added; using water samples collected from Tokyo Bay on 29 September 1999 at different depths $(0,10$ and $16 \mathrm{~m})$. Error bars indicate $1 \mathrm{SD}$ fraction, abundance of free-living or attached nanoflagellates and chl a showed some variability with time, but did not increase significantly compared to the increase in water temperature. One exception was the abundance of bacteria, which showed a significant increase in the May sample.

The transfer rates in untreated incubations were significantly higher $(p<0.01)$ than those in the thiuram-treatment incubation, except on 16 February and 12 April ( 0 and $43 \mathrm{~m}$ depth), and also significantly higher $(\mathrm{p}<0.001)$ than the $\mathrm{NaN}_{3}$-treatment incubation

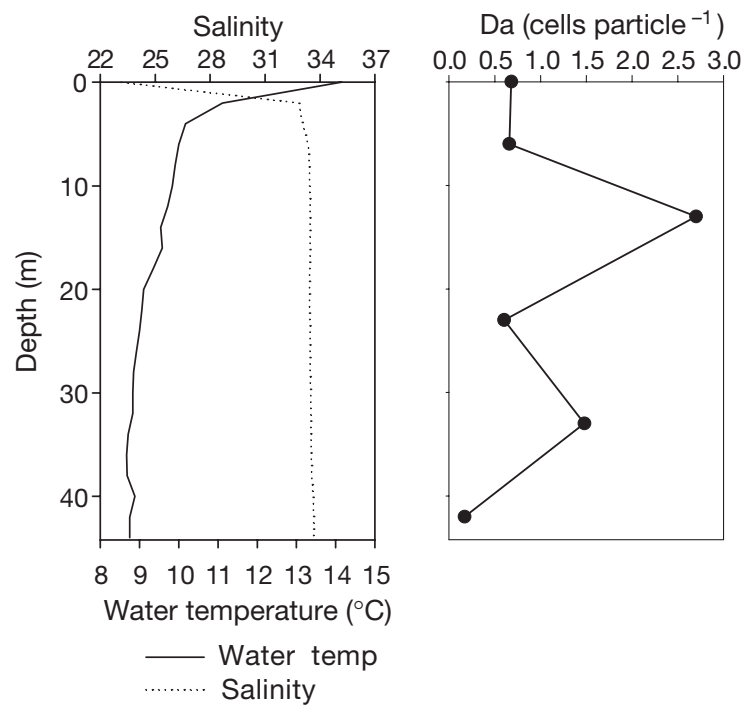

Particles in 5-20 $\mu \mathrm{m}$ fraction Bacteria $\left(10^{6}\right.$ cells $\left.\mathrm{ml}^{-1}\right)$ (particles $\mathrm{ml}^{-1}$ ) FF and $\mathrm{AF}\left(10^{2}\right.$ cells $\left.\mathrm{ml}^{-1}\right)$
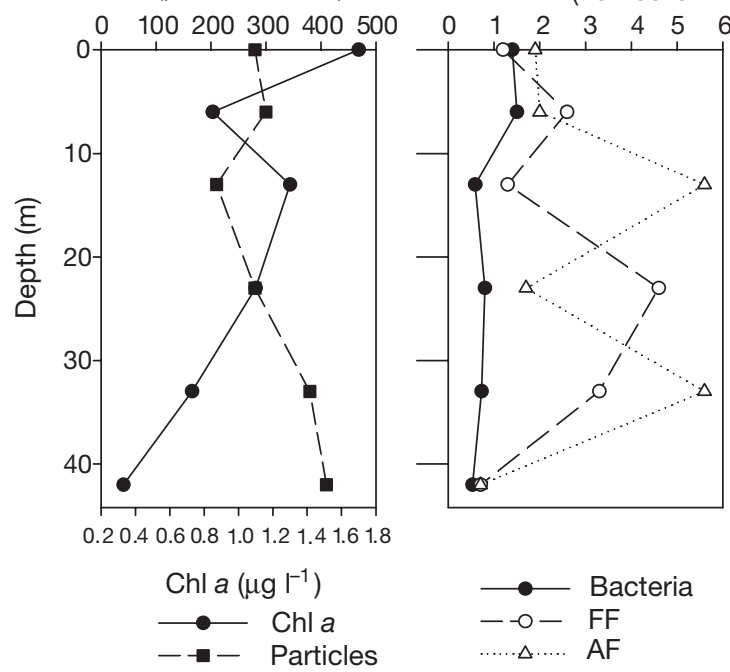

Fig. 4. Vertical profiles of water temperature, salinity, density of attached nanoflagellates (Da), total particle number in the 5-20 um fraction, concentration of chlorophyll a (chl a), bacterial abundance (Bacteria) and abundance of free-living or attached nanoflagellates ( $\mathrm{FF}$ or $\mathrm{AF}$, respectively) at Otsuchi Bay on 24 May 2000 
except for 12 April (0 and $43 \mathrm{~m}$ depth) (Table 2). The $\mathrm{V}_{\mathrm{N}} / \mathrm{V}_{\mathrm{A}}$ ratio ranged from 1.1 to 10 during the observation period, but significant correlations between the change of the $\mathrm{V}_{\mathrm{N}} / \mathrm{V}_{\mathrm{A}}$ ratio and other parameters were not observed ( $p>0.05, \mathrm{n}=8$ or 9 ), except for water temperature $(\mathrm{R}=0.693, \mathrm{p}<0.05, \mathrm{n}=9)$. The ingestion rate of fluorescent beads by protozoa was under the

Table 1. Depth profile of transfer rate (mean, $\mathrm{n}=5$ ) of fluorescent beads to micro-suspended particles (5 to $20 \mu \mathrm{m}$ in diameter) with or without metabolic inhibitors, ingestion rate (mean, $\mathrm{n}=3$ ) of beads in cultures without metabolic inhibitors and the $\mathrm{V}_{\mathrm{N}} / \mathrm{V}_{\mathrm{A}}$ ratio during the incubation of water samples collected from Tokyo Bay on 29 September 1999 and Otsuchi Bay 24 May 2000. $V_{N}$ : no treatment; $\mathrm{V}_{\mathrm{T}}$ : thiuram treatment; $\mathrm{V}_{\mathrm{A}}: \mathrm{NaN}_{3}$ treatment; $\mathrm{ns}$ : statistically significant increase was not observed $(p>0.05) . \pm$ SE is shown

\begin{tabular}{|c|c|c|c|c|c|}
\hline \multirow{2}{*}{$\begin{array}{l}\text { Depth } \\
\text { (m) }\end{array}$} & \multicolumn{3}{|c|}{ Transfer rate $\left(10^{2}\right.$ particles $\left.\mathrm{ml}^{-1} \mathrm{~h}^{-1}\right)$} & \multirow{2}{*}{$\begin{array}{l}\text { Ingestion rate } \\
\left(10^{2} \text { particles }\right. \\
\left.\mathrm{ml}^{-1} \mathrm{~h}^{-1}\right)\end{array}$} & \multirow[t]{2}{*}{$\mathrm{V}_{\mathrm{N}} / \mathrm{V}_{\mathrm{A}}( \pm \mathrm{SE})$} \\
\hline & $\mathrm{V}_{\mathrm{N}}$ & $\mathrm{V}_{\mathrm{T}}$ & $\mathrm{V}_{\mathrm{A}}$ & & \\
\hline \multicolumn{6}{|c|}{ Tokyo Bay } \\
\hline 0 & $33 \pm 2$ & $3.3 \pm 0.5$ & $3.9 \pm 0.4$ & ns & $8.5 \pm 0.1$ \\
\hline 10 & $11 \pm 0.1$ & $1.5 \pm 0.2$ & $2.6 \pm 0.1$ & ns & $4.2 \pm 0.1$ \\
\hline 16 & $16 \pm 0.2$ & $4.1 \pm 0.8$ & $4.7 \pm 0.1$ & ns & $3.5 \pm 0.1$ \\
\hline \multicolumn{6}{|c|}{ Otsuchi Bay } \\
\hline 0 & $7.7 \pm 0.5$ & ns & $0.50 \pm 0.10$ & $0.051 \pm 0.019$ & $10 \pm 0.2$ \\
\hline 13 & $2.5 \pm 0.6$ & ns & $0.25 \pm 0.06$ & ns & $9.9 \pm 0.3$ \\
\hline 42 & $0.38 \pm 0.01$ & $0.30 \pm 0.07$ & $0.27 \pm 0.02$ & $0.017 \pm 0.002$ & $1.4 \pm 0.1$ \\
\hline
\end{tabular}

Table 2. Daily changes of transfer rate (mean, $\mathrm{n}=5$ ) of fluorescent beads to micro-suspended particles (5 to $20 \mu \mathrm{m}$ in diameter) with or without metabolic inhibitors, ingestion rate (mean, $\mathrm{n}=3$ ) of beads in cultures without metabolic inhibitors and the $\mathrm{V}_{\mathrm{n}} / \mathrm{V}_{\mathrm{A}}$ ratio during the incubation of water samples collected from the surface layer (0 to $10 \mathrm{~m}$ ) in Otsuchi Bay from 16 February to 24 May 2000 and from Aburatsubo Bay from 15 August to 5 September 2000. $V_{\mathrm{N}}$ : no treatment; $\mathrm{V}_{\mathrm{T}}$ : thiuram treatment; $\mathrm{V}_{\mathrm{A}}: \mathrm{NaN}_{3}$ treatment; $\mathrm{ns}$ : statistically significant increase was not observed $(p>0.05) . \pm$ SE is shown

\begin{tabular}{|c|c|c|c|c|c|}
\hline \multirow[t]{2}{*}{ Date } & \multicolumn{3}{|c|}{$\begin{array}{c}\text { Transfer rate } \\
\left(\text { particles } \mathrm{ml}^{-1} \mathrm{~h}^{-1} \text { ) }\right.\end{array}$} & \multirow{2}{*}{$\begin{array}{c}\text { Ingestion rate } \\
(\text { particles } \\
\left.\mathrm{ml}^{-1} \mathrm{~h}^{-1}\right)\end{array}$} & \multirow[t]{2}{*}{$\begin{array}{l}\mathrm{V}_{\mathrm{N}} / \mathrm{V}_{\mathrm{A}} \\
( \pm \mathrm{SE})\end{array}$} \\
\hline & $\mathrm{V}_{\mathrm{n}}$ & $\mathrm{V}_{\mathrm{T}}$ & $\mathrm{V}_{\mathrm{A}}$ & & \\
\hline \multicolumn{6}{|c|}{ Otsuchi Bay } \\
\hline 16 Feb & $74 \pm 2$ & $48 \pm 15$ & $12 \pm 2$ & ns & $6.4 \pm 0.2$ \\
\hline 6 Apr & $63 \pm 8$ & $14 \pm 3$ & $17 \pm 5$ & ns & $3.7 \pm 0.3$ \\
\hline 7 Apr & $65 \pm 11$ & ns & $28 \pm 6$ & ns & $2.3 \pm 0.3$ \\
\hline $8 \mathrm{Apr}$ & $30 \pm 2$ & ns & $16 \pm 3$ & ns & $1.9 \pm 0.2$ \\
\hline 9 Apr & $55 \pm 11$ & $28 \pm 3$ & $18 \pm 4$ & ns & $3.0 \pm 0.3$ \\
\hline 10 Apr & $47 \pm 4$ & $13 \pm 3$ & $17 \pm 4$ & ns & $2.8 \pm 0.2$ \\
\hline 11 Apr & $63 \pm 8$ & $22 \pm 2$ & $9.6 \pm 2.5$ & ns & $6.5 \pm 0.3$ \\
\hline 12 Apr & $40 \pm 4$ & $39 \pm 6$ & $36 \pm 8$ & ns & $1.1 \pm 0.2$ \\
\hline 24 May & $750 \pm 50$ & ns & $50 \pm 10$ & ns & $10 \pm 0.2$ \\
\hline \multicolumn{6}{|c|}{ Aburatsubo Bay } \\
\hline 15 Aug & $4.3 \pm 0.2$ & $0.86 \pm 0.08$ & $0.37 \pm 0.12$ & ns & $4.7 \pm 0.1$ \\
\hline 22 Aug & $6.0 \pm 0.6$ & $0.45 \pm 0.08$ & $0.76 \pm 0.12$ & ns & $6.5 \pm 0.6$ \\
\hline 29 Aug & $14 \pm 1$ & $1.6 \pm 0.2$ & $2.1 \pm 0.1$ & ns & $6.7 \pm 0.1$ \\
\hline 5 Sep & $13 \pm 0.4$ & $2.3 \pm 0.3$ & $2.4 \pm 0.2$ & $0.50 \pm 0.0$ & $5.3 \pm 0.1$ \\
\hline
\end{tabular}

detection limit and the contribution of ingestion rate by (Table 2).

Periodic changes in biological parameters and in the transfer rates of fluorescent beads to particles in the 5-20 $\mu \mathrm{m}$ fraction from August to September 2000 were also examined using the water samples collected from Aburatsubo Bay (Fig. 6, Table 2). Water temperature at Aburatsubo Bay remained almost constant, while chl a changed from 0.76 to $5.3 \mu \mathrm{g} \mathrm{l}^{-1}$ during the observation period (Fig. 6). In addition, the densities of attached nanoflagellates, the number of particles in the 5-20 $\mu \mathrm{m}$ fraction and the abundance of attached nanoflagellates changed significantly, and had their maximum on 29 August 2000, which was similar to chl $a$. The transfer rates in untreated incubations were significantly higher $(p<0.001)$ than those in the thiuram- or $\mathrm{NaN}_{3}$-treatment incubations (Table 2). Although biological parameters changed as indicated above, the $\mathrm{V}_{\mathrm{N}} / \mathrm{V}_{\mathrm{A}}$ ratio did not change much during the observation period and the trend of the $\mathrm{V}_{\mathrm{N}} / \mathrm{V}_{\mathrm{A}}$ ratio was similar to that in incubation temperature. The contribution of ingestion rate by protozoa to the transfer rate was also less than $5 \%$ (Table 2).

\section{Effect of incubation temperature on transfer rate of fluorescent beads to re-suspended particles collected by sediment trap}

The effect of incubation temperature on the transfer rates of fluorescent beads to the 5-20 $\mu \mathrm{m}$ particles was examined using the resuspended particles collected by the sediment trap deployed at Otsuchi Bay (Fig. 7). Among the samples, under 4 different incubation temperatures, differences in biological parameters (bacteria:

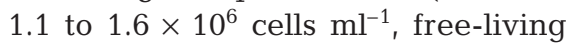
nanoflagellates: 3.7 to $4.0 \times 10^{2}$ cells $\mathrm{ml}^{-1}$, attached nanoflagellates: 3.9 to $6.8 \times 10^{2}$ cells $\mathrm{ml}^{-1}$, density of attached nanoflagellates: 0.21 to 0.40 cells particle ${ }^{-1}$ ) during an incubation period of $18 \mathrm{~h}$ were less than $25 \% \mathrm{CV}$. The number of particles in the 5-20 $\mu \mathrm{m}$ 
fraction (1.4 to $\left.1.8 \times 10^{3} \mathrm{ml}^{-1}\right)$ did not change significantly ( $p>0.05)$ and was at a similar level to those in the ambient water samples from Aburatsubo Bay in summer.

All of the transfer rates in the untreated incubation, under 4 different temperature conditions (3.0 to $20.0^{\circ} \mathrm{C}$ ), were significantly higher than those in the $\mathrm{NaN}_{3}$-treatment incubations ( $\mathrm{p}<0.01$; Fig. 7 ), and the transfer rates obtained from untreated incubation under 4 different temperature conditions had a peak at $14.0^{\circ} \mathrm{C}$, while those in the $\mathrm{NaN}_{3}$-treatment $\left(\mathrm{V}_{\mathrm{A}}\right)$ incubations showed an increase proportional to temperature $\left(\mathrm{V}_{\mathrm{A}}=1.1 \times\right.$ (incubation temperature) $+27, \mathrm{R}^{2}=$ $0.931, \mathrm{p}<0.05, \mathrm{n}=4)$. The $\mathrm{V}_{\mathrm{N}} / \mathrm{V}_{\mathrm{A}}$ ratio also peaked in the $14.0^{\circ} \mathrm{C}$ incubation. The contribution of ingestion rate by protozoa to transfer rate was less than $5 \%$.
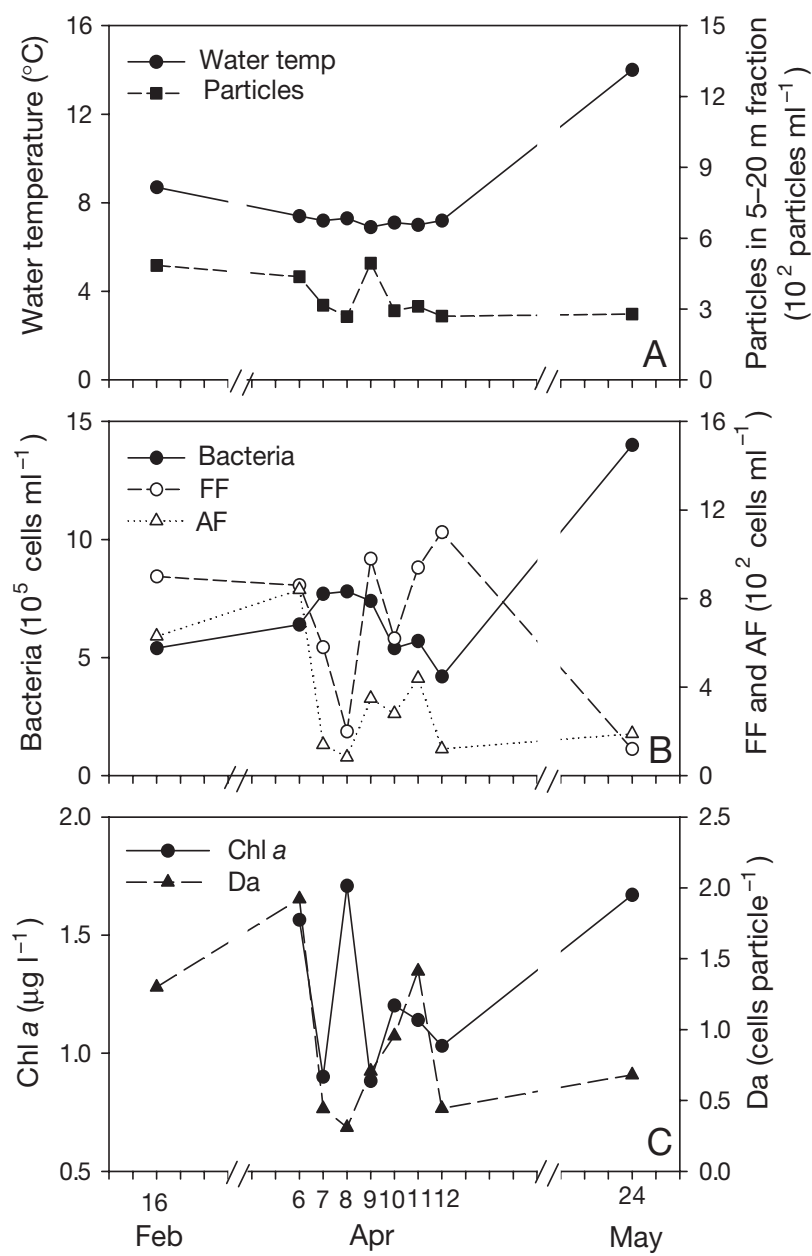

Fig. 5. Time series in (A) water temperature and total particle number in the 5-20 $\mu \mathrm{m}$ fraction, (B) bacterial abundance (Bacteria) and abundance of free-living and attached nanoflagellates ( $\mathrm{FF}$ and $\mathrm{AF}$, respectively), (C) concentration of chlorophyll a ( $\mathrm{chl}$ a) and density of attached nanoflagellates per particle (Da) from 16 February to 24 May 2000 at the surface of Otsuchi Bay

\section{DISCUSSION}

\section{Flow cytometry and experimental design for determination of particle flux of SMP to larger suspended particles}

This study focuses on a new approach for quantitatively examining the microbial enhancement of aggregation by using flow cytometry with fluorescent beads and 2 types of metabolic inhibitors. Most previous studies on biological stimulation of aggregation were limited to qualitative analysis during the course of aggregation (reviewed in Biddanda 1985). By using fluorescent beads as a tracer particle, transport of a particle can be detected by flow cytometry without interference from suspended particles. More impor-
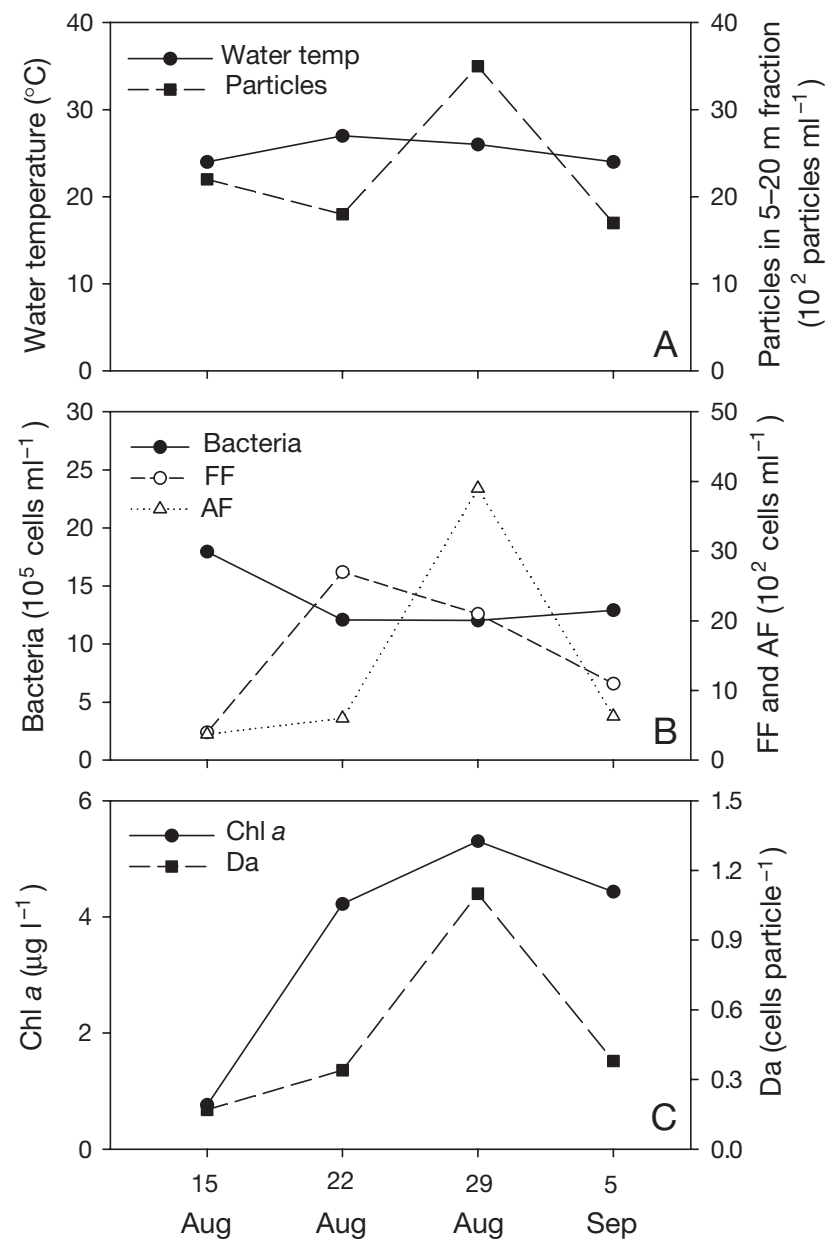

Fig. 6. Time series in (A) water temperature and total particle number in the 5-20 $\mu \mathrm{m}$ fraction, (B) bacterial abundance (Bacteria) and abundance and free-living or attached nanoflagellates ( $\mathrm{FF}$ and $\mathrm{AF}$, respectively), (C) concentration of chlorophyll a ( $\mathrm{chl} a$ ) and density of attached nanoflagellates per particle (Da) from15 August to 5 September 2000 at the surface of Aburatsubo Bay 


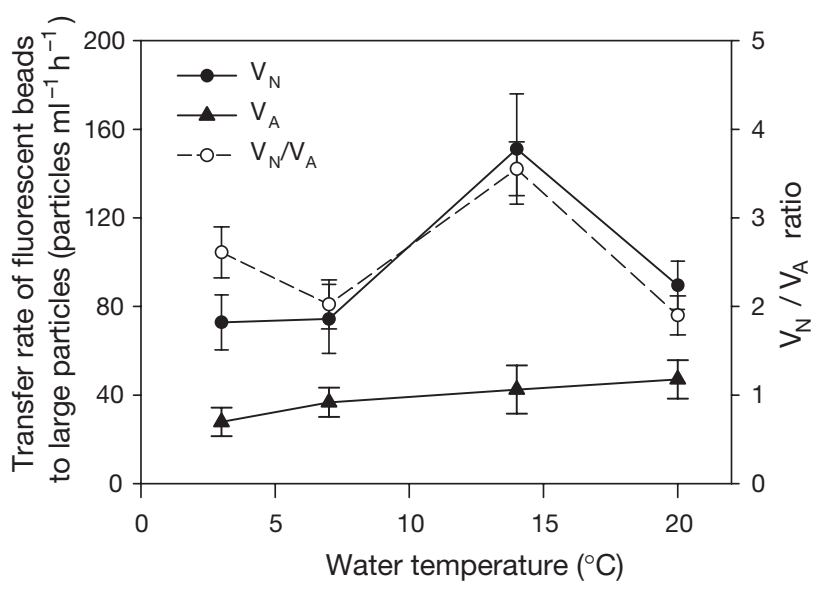

Fig. 7. Relationships between incubation temperature and the transfer rate of fluorescent beads to MSP in untreated culture $\left(V_{N}\right)$, in the $\mathrm{NaN}_{3}$ added culture $\left(\mathrm{V}_{\mathrm{A}}\right)$ and the $\mathrm{V}_{\mathrm{N}} / \mathrm{V}_{\mathrm{A}}$ ratio in the experiment using resuspended aggregates collected by sediment trap at Otsuchi Bay from 13 to 15 March 2000. Error bars indicate $1 \mathrm{SE}$

tantly, this flow cytometric technique does not need any pre-treatment such as particle collection; therefore, the creation of artifacts, such as change of particle size distribution and additional particle transfer during pre-treatment, is minimized. One possible restriction of this technique is that it requires more than 450 particles $\mathrm{ml}^{-1}$ in the $5-20 \mu \mathrm{m}$ fraction to measure enough particles during the standard 1-2 min flow cytometer sampling period for statistical reliability. It may, therefore, be difficult to apply this technique to samples from oligotrophic waters.

The fluorescent beads used in this study may have different properties from natural marine colloids in specific gravity and surface stickiness. However, collision frequency by differential sedimentation is mainly determined by the settling velocity of the 5-20 $\mu \mathrm{m}$ sized particle rather than that of the fluorescent beads and the difference in stickiness is canceled in a $\mathrm{V}_{\mathrm{N}} / \mathrm{V}_{\mathrm{A}}$ ratio of transfer rate in 2 different cultures (Fukuda \& Koike 2000). Regarding the effect of inhibitors (thiuram and $\mathrm{NaN}_{3}$ ) on beads stickiness, the size distribution of beads in filtered seawater did not change significantly with or without inhibitors during a $24 \mathrm{~h}$ incubation period (data not shown). $\mathrm{NaN}_{3}$ chelates cations such as $\mathrm{Mg}^{2+}$ and $\mathrm{Ca}^{2+}$, which in turn leads negatively charged material to stick to the beads, but the concentration of $\mathrm{NaN}_{3}$ in our experiments (3.1 mM) was insufficient to chelate all of the $\mathrm{Mg}^{2+}$ and $\mathrm{Ca}^{2+}$ in the cultures (more than 32 and $6.2 \mathrm{mM}$, respectively, Wilson 1975). Therefore, we considered that the use of inhibitors did not directly change the stickiness of particles.

To compare our results with the aggregation processes in marine environments, the effects of laminar or turbulent shear must be considered, since only Brownian motion and differential sedimentation occur in our experimental bottles. The effectiveness of advective transport induced by sinking or by shear compared with diffusive transport is represented as the Péclet number (reviewed in Karp-Boss et al. 1996). Because the size of SMP $(0.4$ to $1 \mu \mathrm{m})$ is in the upper bracket of colloidal particles ( $1 \mathrm{~nm}$ to $1 \mathrm{~mm}$ ), diffusivity of SMP is calculated using Eq. (2) (see below). For encounters between SMP (0.4 to $1 \mu \mathrm{m})$ and particles in the 5-20 $\mu \mathrm{m}$ fraction by differential sedimentation, the Péclet number $(\mathrm{Pe})$ is 2.4 to 73 assuming an average sedimentation velocity of 1 to $3 \mu \mathrm{m} \mathrm{s}^{-1}$ (Bienfang 1985). On the other hand, the Péclet number for particles in steady shear $\left(P e_{\text {sheari }}\right.$ reviewed in Karp-Boss et al. 1996) is 1.7 to 69 and 17 to 690 with energy dissipation rates of $1 \times 10^{-4}$ and $1 \times 10^{-2} \mathrm{~cm}^{2} \mathrm{~s}^{-3}$, respectively (Oakey 1985). These $P e$ and $P e_{\text {shear }}$ numbers indicate that an increase in encounter rate under the existence of shear reaches a maximum about 2 times higher than that without shear (Karp-Boss et al. 1996).

\section{Importance of biological processes for the aggregation process}

In this study, transfer rates of fluorescent beads to particles in the 5-20 $\mu \mathrm{m}$ fraction in seawater samples collected from 3 coastal areas of Japan were determined. Several lines of evidence indicate that biologically mediated physical collision is involved in the transfer of fluorescent submicron-sized beads to particles in the 5-20 $\mu \mathrm{m}$ fraction. The first line of evidence is that comparison between the measured transfer rate of fluorescent beads to particles in the 5-20 $\mu \mathrm{m}$ fraction and the ingestion rate of the beads by protozoa associated with the particles showed that most of the transfer process was the result of physical processes, i.e. physical collision and subsequent sticking of the beads to particles in the 5-20 $\mu \mathrm{m}$ fraction (Tables $1 \& 2$ ). The second line of evidence is that most of the transfer rates obtained in untreated incubation were significantly higher than those in the $\mathrm{NaN}_{3}$-treatment incubation (Tables 1 \& 2). This suggests that biological processes stimulate the aggregation process between submicronsized beads and particles in the 5-20 $\mu \mathrm{m}$ fraction. In addition, temperature dependency of the transfer rate also supports the possible dominance of biological rocesses in untreated incubation, since transfer rate in untreated incubation had an optimum temperature, while that in the $\mathrm{NaN}_{3}$-treatment incubation increased proportionally with increase of incubation temperature (Fig. 7). The mean values of the $\mathrm{V}_{\mathrm{N}} / \mathrm{V}_{\mathrm{A}}$ ratio at each sampling site were 4.3, 5.4 and 5.8 for Tokyo Bay, Otsuchi Bay and Aburatsubo Bay, respectively. Since 
these mean values of the $\mathrm{V}_{\mathrm{N}} / \mathrm{V}_{\mathrm{A}}$ ratio is greater than 1 , even when $\mathrm{V}_{\mathrm{A}}$ is doubled to estimate the physical encounter rate in a mixed layer (see above), these results suggest that biological stimulation of the transfer process of SMP into the 5-20 $\mu \mathrm{m}$ fraction exists in at least the upper layer of coastal waters.

Enhancement of the transfer process of SMP into the 5-20 $\mu \mathrm{m}$ fraction in the coastal waters was also inhibited by the addition of thiuram, except for a few occasions at Otsuchi Bay (Tables 1 \& 2). Although thiuram has been reported to inhibit protein synthesis in eukaryotic cells (Taylor \& Pace 1987), the exact mechanisms of the inhibitory effect of thiuram on the incorporation process of SMP into the 5-20 $\mu \mathrm{m}$ particles are difficult to identify. Taylor \& Pace (1987) reported that thiuram inhibited the growth of protozoa and chlorophyll synthesis of phytoplankton. Thiuram also probably inhibits other metabolic pathways in eukaryotes. If thiuram is assumed to be a specific metabolic inhibitor for eukaryotes, the results of this observation suggest that the transfer process of SMP into the 5-20 $\mu$ m fraction was caused by eukaryotes such as nanoflagellates separately from particle ingestion (Fukuda \& Koike 2000).

\section{Mechanisms for biological stimulation of particle aggregation}

Several mechanisms are potential candidates for the biological stimulation of particle aggregation observed in this study. The first mechanism is the feeding current of attached nanoflagellates stimulating the collision rate between SMP and 5-20 $\mu \mathrm{m}$ sized particles (Fukuda \& Koike 2000). This process is similar to the advection between SMP and settling large particles (Karp-Boss et al. 1996). The effect of this physical forcing increases proportionally with the increase of density of attached nanoflagellates on particles in the 5-20 $\mu \mathrm{m}$ fraction (Da) and increases with the average velocity of the feeding current of attached nanoflagellate assemblages, which may be affected by prey abundance, water temperature (Vaqué et al. 1994) or the species composition of nanoflagellates. The second mechanism is the increase in stickiness of particles in the 5-20 $\mu \mathrm{m}$ fraction due to bacterial, protozoa and phytoplankton metabolisms (Biddanda 1985, Koike et al. 1990, Kiørboe \& Hansen 1993, Nagata 2000, Passow 2000). Sticky extracellular materials released from microbes stimulate the aggregation process by increasing the probability of particles sticking together after collision.

To examine the mechanisms stimulating SMP aggregation by biological processes, regression analysis between the $\mathrm{V}_{\mathrm{N}} / \mathrm{V}_{\mathrm{A}}$ ratio and experimental condition and abundance of microorganisms was performed.
Significant correlation was observed with Da $(\mathrm{R}=$ $0.630, \mathrm{p}<0.05, \mathrm{n}=22$ ), concentration of chlorophyll a $(\mathrm{R}=0.518, \mathrm{p}<0.05, \mathrm{n}=18)$, bacterial abundance $(\mathrm{R}=$ $0.489, \mathrm{p}<0.05, \mathrm{n}=22)$ and incubation temperature $(\mathrm{R}=$ $0.569, \mathrm{p}<0.01, \mathrm{n}=22$ ), but not with total particle number of particles in the 5-20 $\mu \mathrm{m}$ fraction and abundance of free-living or attached nanoflagellates $(\mathrm{p}>0.05, \mathrm{n}=$ 22 for these 3 variables). Positive correlation with Da suggests that the feeding current of attached nanoflagellates played an important role in experimental cultures. Also, positive correlation with chl a may indicate the change in particle stickiness in experimental cultures. As regards bacterial abundance, however, it is not clear why it correlates with the $\mathrm{V}_{\mathrm{N}} / \mathrm{V}_{\mathrm{A}}$ ratio, since the biological stimulation observed was inhibited by the eukaryotic inhibitor, thiuram. Taylor \& Pace (1987) reported that some bacterial activities were inhibited by addition of thiuram. Bacterial release of organic material and ectoenzymes or bacterial hydrolysis may stimulate the transfer process of SMP into the 5-20 $\mu \mathrm{m}$ fraction by changing particle stickiness. On the other hand, bacterial abundance may affect protozoan grazing rather than particle stickiness.

The correlation between the $\mathrm{V}_{\mathrm{N}} / \mathrm{V}_{\mathrm{A}}$ ratio and the abundance of nanoflagellates was not significant $(\mathrm{p}>$ $0.05, \mathrm{n}=22$ ). This suggests released materials produced by nanoflagellates did not contribute to the stimulation of the transfer process of SMP into the 5-20 $\mu \mathrm{m}$ fraction. Additionally, increased incubation temperature may affect these processes by stimulating protozoan grazing activity and release rate of extracellular materials by phytoplankton (Zlotnik \& Dubinsky 1989, Rivkin et al. 1999). The increase of stickiness caused by the above processes would be cumulative during the incubation period. However, a non-liner time course of bead number on particles in the 5-20 $\mu \mathrm{m}$ fraction was not observed (e.g. Fig. 3).

Alldredge \& McGillivary (1991) reported the particle stickiness to be 0.60 for amorphous detrital aggregates and 0.88 for flocculated diatoms. Even if the stickiness of marine aggregates increases to their maximum value $(=1)$, the coagulation rate will only be stimulated 1.1 to 1.7 times. The $\mathrm{V}_{\mathrm{N}} / \mathrm{V}_{\mathrm{A}}$ ratios obtained in these experiments were significantly higher than those in most other experiments (the average of 3 locations ranged from 4.3 to 5.8) and the maximum $\mathrm{V}_{\mathrm{N}} / \mathrm{V}_{\mathrm{A}}$ ratio reached 10 (Tables $1 \& 2$ ). The change in particle stickiness was not determined, but this high $\mathrm{V}_{\mathrm{N}} / \mathrm{V}_{\mathrm{A}}$ ratio value suggests that the increase in stickiness would be a minor contributing factor to the observed biological stimulation of aggregation, even if the increase in stickiness occurs.

On the other hand, feeding currents of attached nanoflagellates could explain the stimulation of the transfer process of SMP into the 5-20 $\mu \mathrm{m}$ fraction to a significant extent. The effectiveness of both feeding 
current of attached nanoflagellate on a particle and particle settling on particle encounter rate can be expressed as the Sherwood number $(S h)$, which indicates the relative enhancement of particle encounter due to advection against a purely diffusional encounter. The $S h$ number under uniform flow is given by:

$$
S h=\frac{1}{2}\left[1+\left(1+2 \frac{U r_{1}}{D}\right)^{\frac{1}{3}}\right]
$$

where $U$ is the settling velocity of $5-20 \mu \mathrm{m}$ particles or velocity of SMP in the flow field of feeding current, $r_{1}$ is the radius of the $5-20 \mu \mathrm{m}$ particles and $D$ is Brownian diffusivity (Karp-Boss et al. 1996). Brownian diffusivity is determined by the equation:

$$
D=\frac{K T}{6 \pi \mu r_{2}}
$$

where $K$ is Boltzmann's constant, $T$ is the absolute temperature, $\mu$ is dynamic viscosity, $r_{2}$ is the radius of SMP. Assuming that 1 attached nanoflagellate generating a steady flow of $220 \mu \mathrm{m} \mathrm{s}^{-1}$, which is an average swimming speed of nanoflagellates (85 to $360 \mathrm{~mm} \mathrm{~s}^{-1}$; Goldman 1984), harbors on one 5-20 $\mu \mathrm{m}$ particle and that the average settling velocity of the particle is 1 to $3 \mu \mathrm{m}$ $\mathrm{s}^{-1}$ (Bienfang 1985), then the Sh number for feeding current $\left(S h_{\mathrm{fc}}\right)$ or for particle settling $\left(S h_{\mathrm{st}}\right)$ would be 6.0 to 9.2 or 1.5 to 2.6 , respectively. As a first order approximation, the $\mathrm{V}_{\mathrm{N}} / \mathrm{V}_{\mathrm{A}}$ ratio is regarded to be $S h_{\mathrm{fc}} / S h_{\mathrm{st}}$ neglecting particle settling in $\mathrm{V}_{\mathrm{N}}$. The estimated $\mathrm{V}_{\mathrm{N}} / \mathrm{V}_{\mathrm{A}}$ ratio is 3.3 to 4.7 . In our observation, the mean value of $\mathrm{V}_{\mathrm{N}} / \mathrm{V}_{\mathrm{A}}$ when 1 flagellate attaches to a 5-20 $\mathrm{mm}$ sized particle was 6.0 to 6.7 (95\% CI), which is estimated from the regression line $\left(\log \left[\mathrm{V}_{\mathrm{N}} / \mathrm{V}_{\mathrm{A}}\right]=0.86 \mathrm{Log}\right.$

Table 3. Results of backward stepwise multiple regression using data from water samples. The dependent variable was the $\mathrm{V}_{\mathrm{N}} / \mathrm{V}_{\mathrm{A}}$ ratio, and independent variables were total particle number in the 5-20 $\mu \mathrm{m}$ fraction (PN), abundance of freeliving nanoflagellates and attached nanoflagellates, density of attached nanoflagellates (Da), bacterial abundance (Bacteria), concentration of chlorophyll a (chl a) and incubation temperature (Temp). The limit of the $F$ value was set to 2 to eliminate dependent variables. The lower line shows the result of similar regression using all of the data from incubations at in situ temperature (water samples and resuspended aggregates). Because of the lack of data with chla, it was not used as

\begin{tabular}{|c|c|c|}
\hline Independant varia & & $\mathrm{R}^{2}$ \\
\hline \multicolumn{3}{|c|}{ Using only water samples $(n=18)$} \\
\hline $\mathrm{PN}^{*} \quad \mathrm{Da}^{* * *}$ & Bacteria* Temp** & 0.826 \\
\hline \multicolumn{3}{|c|}{ Using water samples and resuspended aggregates } \\
\hline $\mathrm{Da}^{* * *} \mathrm{Temp}^{* *}$ & & 0.776 \\
\hline
\end{tabular}
an independent variable. ${ }^{*} \mathrm{p}<0.05,{ }^{* *} \mathrm{p}<0.01,{ }^{* * *} \mathrm{p}<0.001$
$\mathrm{Da}+0.80: \mathrm{R}^{2}=0.398, \mathrm{p}<0.01, \mathrm{n}=22$ ). Therefore, feeding current of attached nanoflagellates could explain a significant portion of biological stimulation.

The assumed velocity of the feeding current $(220 \mu \mathrm{m}$ $\mathrm{s}^{-1}$ ) may be an over-estimate, when the contribution of a raptorial feeder without feeding current to attached nanoflagellates population is high. Artolozaga et al. (2000) reported that attached nanoflagellates associated with the aggregate-water interface consisted mainly of suspension feeders. In addition, the results of backward stepwise regression analysis suggests that the feeding current is a more important mechanism to explain the observed transfer process of SMP into the 5-20 $\mathrm{mm}$ fraction than chl a (Table 3).

\section{CONCLUSIONS}

In previous studies on SMP aggregation, the primary focus of the discussion was the need of biological activity for the aggregation processes (reviewed in Biddanda 1985). However, this study is the first to attempt to examine the relative importance of physical forcing by biological and physico-chemical processes on the transfer process of SMP into the 5-20 $\mu \mathrm{m}$ fraction. Several lines of evidence obtained in this study indicate that the intensity of biological stimulation is as important as or even more so than the physical transfer process of SMP into the 5-20 $\mu \mathrm{m}$ fraction in coastal environments. Although it is not clear what kind of biological mechanism stimulates the particle aggregation process, the sensitivity to the eukaryotic inhibitor, thiuram, and regression analysis suggest that activity of attached nanoflagellates and phytoplankton play an important role in the aggregation process of marine particles. The number of attached nanoflagellates on marine snow in previous studies (reviewed in Kiørboe 2001) and sinking velocity of marine snow (Alldredge \& Gotschalk 1988) suggest that the aggregation by feeding current is potentially effective bellow the euphotic zone, exceeding the encounter physical aggregation process, probably due to differential sedimentation (e.g. for $1 \mathrm{~mm}$ of marine snow, Da is 440 and the sinking velocity is $580 \mu \mathrm{m} \mathrm{s}^{-1}$ ). Moreover, Wörner et al. (2000) showed that suspension- and filter feeders colonized more rapidly on aggregates than raptorial feeders. This suggests that the suspension- and filter-feeding attached nanoflagellates increase at the beginning of the decay phase of phytoplankton blooming. In addition, extracellular materials released by phytoplankton such as transparent exoploymer particles (TEP) are accumulated during phytoplankton bloom (reviewed in Passow 2002). Putting together these processes, microbial stimulation of colloidal aggregation plays important roles in oceanic carbon cycling. 
Acknowledgements. We thank the staff of the International Coastal Research Center and the Marine Biological Research Institute of Japan for assistance. Thanks are also due to J. G. Mitchell for helpful comments on the manuscript. This study was supported by grants from the JSPS Research Fellowships for Young Scientists (13-72502) Program and a Grant-in-Aid for Creative Basic Research 12NP0201 (DOBIS).

\section{LITERATURE CITED}

Alldredge AL, Gotschalk C (1988) In situ settling behavior of marine snow. Limnol Oceanogr 33:339-351

Alldredge AL, McGillivary P (1991) The attachment probabilities of marine snow and their implications for particle coagulation in the ocean. Deep Sea Res 38:431-443

Artolozaga I, Ayo B, Latatu A, Azúa I, Unanue M, Iriberri J (2000) Spatial distribution of protists in the presence of macroaggregates in a marine system. FEMS Microbiol Ecol 33:191-196

Biddanda BA (1985) Microbial synthesis of macroparticulate matter. Mar Ecol Prog Ser 20:241-251

Bienfang PK (1985) Size structure and sinking rates of various microparticulate constituents in oligotrophic Hawaiian waters. Mar Ecol Prog Ser 23:143-151

Caron DA (1987) Grazing of attached bacteria by heterotrophic microflagellates. Microb Ecol 13:203-218

Fukuda H, Koike I (2000) Feeding currents of particleattached nanoflagellates - a novel mechanism for aggregation of submicron particles. Mar Ecol Prog Ser 202: 101-112

Goldman JC (1984) Conceptual role for microaggregation in pelagic waters. Bull Mar Sci 35:462-476

Holm-Hansen O, Lorenzen C, Holmes RW, Strickland JDH (1965) Fluorometric determination of chlorophyll. J Cons Cons Int Explor Mer 30:3-15

Jackson GA, Burd AB (1998) Aggregation in the marine environment. Environ Sci Technol 32:2805-2814

Johnson BD, Kepkay PE (1992) Colloid transport and bacterial utilization of oceanic DOC. Deep-Sea Res 39:85-869

Karp-Boss L, Boss E, Jumars PA (1996) Nutrient fluxes to planktonic osmotrophs in the presence of fluid motion. Oceanogr Mar Biol Annu Rev 34:71-107

Kerner M, Hohenberg H, Ertl S, Reckermann M, Spotzy A. (2003) Self-organization of dissolved organic matter to micelle-like microparticles in river water. Nature 422: $150-154$

Kiørboe T (2001) Formation and fate of marine snow: smallscale processes with large-scale implications. Sci Mar 65: $57-71$

Kiørboe T, Hansen JLS (1993) Phytoplankton aggregation formation: observation of patterns and mechanisms of cell sticking and the significance of expolymeric material. J Plankton Res 15: 993-1018

Koike I, Hara S, Terauchi K, Kogure K (1990) Role of submicrometre particles in the ocean. Nature 345:242-244

Editorial responsibility: Fereidoun Rassoulzadegan, Villefranche-sur-Mer, France
Mari X, Burd AB (1998) Seasonal size spectra of transparent exopolymeric particles (TEP) in a coastal sea and comparison with those predicted using coagulation theory. Mar Ecol Prog Ser 163:63-76

McCave IN (1984) Size spectra and aggregation of suspended particles in the deep ocean. Deep-Sea Res 31:329-352

Nagata T (2000) Production mechanisms of dissolved organic matter. In: Kirchman DL (ed) Microbial ecology of the oceans. Wiley-Liss incorporation, New York

Nagata T, Koike I (1995) Marine colloids: Their roles in food webs and biogeochemical fluxes. In: Sakai H, Nozaki Y (eds) Biogeochemical processes and ocean flux in the Western Pacific. Terra Scientific Publishing Company, Tokyo

Oakey NS (1985) Statistics of mixing parameters in the upper ocean during JASIN phase 2. J Phys Oceanogr 15: $1662-1675$

Passow U (2000) Formation of transparent exopolymer particles, TEP, from dissolved precursor material. Mar Ecol Prog Ser 192:1-11

Passow U (2002) Transparent exopolymer particles (TEP) in aquatic environments. Prog Oceangr 55:287-333

Porter KG, Feig YS (1980) The use of DAPI for identifying and counting aquatic microflora. Limnol Oceanogr 25:943-948

Quigley MS, Santschi PH, Hung CC, Guo L, Honeyman BD (2002) Importance of acid polysaccharide for ${ }^{234} \mathrm{Th}$ complexation to marine organic matter. Limnol Oceanogr 47: 367-377

Ricker WE (1973) Linear regression in fishery research. J Fish Res Board Can 30: 409-434

Rivkin RB, Putland JN, Anderson MR, Deibel D (1999) Microzooplankton bacterivory and herbivory in the NE subarctic Pacific. Deep-Sea Res 46:2579-2618

Sherr BF, Sherr EB (1983) Enumeration of heterotrophic microprotozoa by epifluorescence microscopy. Estuar Coast Shelf Sci 16:1-7

Sherr BF, Sherr EB, Fallon RD (1987) Use of monodispersed, fluorescently labeled bacteria to estimate in situ protozoan bacterivory. Appl Environ Microbiol 53:958-965

Suzuki R, Ishimaru T (1990) An improved method for the determination of phytoplankton chlorophyll using $\mathrm{N}, \mathrm{N}$ di-methylformamide. J Oceanogr Soc Jpn 46:190-194

Taylor GT, Pace ML (1987) Variability of eukaryote inhibitor for assessing production and grazing mortality of marine bacterioplankton. Appl Environ Microbiol 53:119-128

Vaqué DJ, Gasol JM, Marrasé C (1994) Grazing rates on bacteria: the significance of methodology and ecological factors. Mar Ecol Prog Ser 109:263-274

Wilson TRS (1975) Salinity and the major elements of sea water. In: Riley, JP Skirrow G (eds) Chemical oceanography. Academic Press, London p 365-408

Wörner U, Zimmerman-Tim H, Kausch H. (2000) Succession of protisits on estuarine aggregates. Microb Ecol 40: 209-222

Zlotnik I, Dubinsky Z (1989) The effect of light and temperature on DOC excretion by phytoplankton. Limnol Oceanogr 34:831-839

Submitted: March 12, 2004; Accepted: July 16, 2004

Proofs received from author(s): October 15, 2004 